\title{
Penilaian Tingkat Bahaya Erosi di Sub Daerah Aliran Sungai Cileungsi, Bogor
}

\author{
Nanang Komaruddin \\ Fakultas Pertanian Universitas Padjadjaran \\ Jl. Raya Jatinangor Km. 21 Bandung 40600
}

\begin{abstract}
Evaluation of Erosion Hazard Level in Cileungsi Sub Watershed, Bogor

Land rehabilitation in sub watershed should be done based on the actual land erosion value in order to avoid intensive land degradation. This research has been conductud to make land classification in Cileungsi sub watershed in Bogor West Java based on the erosion hazard level and the soil water infiltration. The erosion hazard was determined by using USLE (Universal Soil Loss Equation) formula, while water infiltration was determined by rain water infiltration level. The result of experiment showed that the erosion hazard level in study area ranged from very light to moderate with area extent of 24,620 ha $(45.59 \%)$ and heavy to very heavy covered 11,540 ha (21.37\%). In general, land with erosion hazard level of heavy to very heavy is located in upper sub watershed. The high value of erosion in Cileungsi Sub-watershed area mainly due to the land cover factor, and the management and soil conservation factor. The condition of infiltration area in the study area was classified as good covered 10,076 ha (18.66\%), natural normal condition covered 6,158 ha (11.40\%), initial critical condition covered 12,398 ha (22.96\%), and slightly critical condition covered 7,528 ha (13.94\%). The lack of land cover vegetation in upper subwatershed Cileungsi is one of the factors that decrease water infiltration and increase erosion hazard
\end{abstract}

Key words: Land rehabilitation, soil conservation, Erosion Hazard Level, USLE.

\begin{abstract}
ABSTRAK
Upaya rehabilitasi lahan di daerah aliran suangi (DAS) harus dilakukan berdasarkan nilai erosi aktual lahan sehingga degradasi lahan yang lebih parah dapat dicegah. Penelitian ini dilakukan untuk mengklasifikasi lahan di sub DAS Cileungsi Bogor Jawa Barat berdasarkan tingkat bahaya erosi dan kondisi resapan air tanah. Tingkat bahaya erosi ditentukan berdasarkan rumus USLE (Universal Soil Loss Equation), sedangkan analisis resapan air didekati melalui tingkat resapan (infiltrasi) air hujan. Hasil penelitian menunjukkan bahwa tingkat bahaya erosi di daerah kajian berkisar dari sangat ringan sampai sedang dengan luas 24.620 ha $(45,59 \%)$ dan berat sampai sangat berat dengan luas 11.540 ha $(21,37 \%)$. Lahan dengan tingkat bahaya erosi berat sampai sangat berat umumnya terdapat di bagian hulu Sub DAS. Penyebab utama besarnya erosi pada wilayah Sub DAS Cileungsi adalah faktor tanaman penutup lahan (C) dan faktor pengelolaan/konservasi tanah (P). Kondisi resapan daerah kajian dikelompokkan kedalam kondisi baik seluas 10.076 ha (18,66\%), kondisi normal alami seluas 6.158 ha $(11,40 \%)$, kondisi mulai kritis seluas 12.398 ha $(22,96 \%)$ dan kondisi agak kritis seluas 7.528 ha (13,94\%). Kurangnya penutup lahan pada bagian hulu Sub DAS merupakan salah satu faktor penyebab penurunan kemampuan tanah meresap air dan meningkatkan bahaya erosi.
\end{abstract}

Kata kunci : Rehabilitasi lahan, konservasi tanah, tingkat bahaya erosi, USLE. 


\section{PENDAHULUAN}

Dalam mendukung pembangunan wilayah Kabupaten Bogor, sejalan dengan diberlakukannya Undang-Undang Otonomi Daerah (UU No. 22 Tahun 1999) diperlukan data sumberdaya lahan terbaru dan akurat. Dengan demikian penggunaan lahan dapat dilakukan secara lebih terarah, produktif dan lestari tanpa menimbulkan kerusakan lahan dan lingkungannya. Wilayah ini dilalui oleh empat daerah aliran sungai (DAS) yaitu Cisadane, Ciliwung, Cipamingkis dan Cileungsi (Yusmandhany, 2004). Hampir 29 \% dari wilayah Bogor dipakai sebagai kawasan pemukiman dan industri (Dishutbun, 2002). Dengan demikian, tingkat bahaya erosi yang berkaitan erat dengan kemampuan infiltrasi tanah dan selanjutnya kualitas lahan di wilayah tersebut terutama di DAS perlu diperhatikan.

Daerah aliran sungai (DAS) merupakan daerah resapan air yang dapat mengatur sistem tata air. Secara alami kualitas DAS dipengaruhi oleh faktor biofisik pembentuk tanah yaitu relief, topografi, fisiografi, iklim, tanah, air, dan vegetasi (Tan, 1991). Namun penggunaan lahan yang berkaitan erat dengan aktivitas manusia menyebabkan keseimbangan ekosistem DAS terganggu. Eksploitasi DAS menimbulkan masalah 1) banjir di musim hujan dan kekeringan di musim kemarau, 2) penurunan debit air sungai, 3) erosi dan sedimentasi, 4) longsor. Secara faktual masalah tersebut telah menimbulkan penurunan produktivitas lahan dan kekurangan air tanah sepanjang tahun.

Pemanfaatan lahan biasanya secara langsung menyebabkan perubahan tata guna lahan di suatu wilayah. Perubahan tata guna lahan seringkali tidak disertai dengan tindakan pencegahan kerusakan lahan, sehingga lahan semakin terdegradasi yang secara kasat mata ditandai dengan tingginya tingkat erosi dan sedimentasi serta rendahnya tingkat resapan air hujan. Alih fungsi lahan oleh manusia umumnya mengubah vegetasi dan pengelolaan lahan. Kedua faktor ini memberikan memberikan kontribusi terbesar terhadap erosi di suatu DAS.

Erosi di DAS umumnya terjadi karena pemanfaatan lahan yang tidak mengindahkan kaidah konservasi tanah dan air. Erosi di suatu lahan menyebabkan hilangnya lapisan atas tanah yang subur untuk menyangga pertumbuhan tanaman (Tan, 1991). Untuk mempertahankan kelestarian produktivitas tanah maka perlu dicegah agar erosi yang terjadi tidak melebihi batas erosi yang dapat diabaikan. Sedangkan jika erosi telah terjadi maka diperlukan upaya rehabilitasi dan konservasi lahan.

Upaya rehabilitasi lahan untuk mengatasi kemerosotan produktivitas sumberdaya lahan (vegetasi, tanah dan air) dan mencegah kerusakan fungsi DAS harus dilakukan dengan metode yang tepat berdasarkan nilai erosi aktualnya. Selain itu rehabilitasi yang tepat memerlukan data kondisi daerah resapan yang dapat diklasifikasikan dengan cara membandingkan infiltrasi potensial dan infiltrasi aktual serta nilai erosi aktualnya.

Berdasarkan pada permasalahan yang diperoleh dari laporan-laporan hasil penelitian dan informasi dari instansi terkait, permasalahan utama di Sub DAS Cileungsi adalah: 1) erosi dan sedimentasi, dan 2) besarnya aliran permukaan dan resapan. Berdasarkan masalah tersebut maka pendekatan dalam penelitian ini adalah melakukan analisis tingkat bahaya erosi dan sedimentasi serta analisis aliran permukaan dan peresapan air hujan ke dalam tanah. Untuk maksud tersebut telah dilakukan serangkaian kegiatan, yaitu penyusunan peta satuan lahan, analisis tingkat bahaya erosi dan sedimentasi serta analisis aliran permukaan dan peresapan air hujan.

Penelitian ini dilakukan untuk mengklasifikasi lahan di sub DAS Cileungsi Jawa Barat berdasarkan tingkat erosi dan kondisi resapan air sehingga didaptkan nilai tingkat bahaya erosi yang akan menjadi dasar rehabilitasi lahan DAS Cileungsi yang tepat dan terarah.

\section{BAHAN DAN METODE PENELITIAN}

Kajian mengenai Rehabilitasi Lahan dan Konservasi Tanah berdasarkan tingkat bahaya erosi di Sub DAS Cileungsi, Kabupaten Bogor meliputi daerah Cileungsi Hulu, Cikeas, Citeureup dan Cikarang seluas lebih kurang 54.000 ha.

\section{Penyusunan Peta Satuan Lahan}

Peta satuan lahan menggambarkan karakteristik dan penyebaran lahan sebagai dasar dalam perhitungan dan pembuatan peta bahaya erosi dan tingkat bahaya erosi serta penentuan lokasi dan tindakan operasional rehabilitasi lahan dan konservasi tanah. Peta satuan lahan disusun dari overlay peta-peta geomorfologi/landform, peta 
geologi/litologi, peta bentuk wilayah/lereng, peta tanah dan peta penggunaan lahan saat ini. Peta dasar yang digunakan adalah peta rupabumi skala 1:25.000 dari Badan Koordinasi Survei dan Pemetaan Nasional (1991). Data/informasi satuan lahan diperoleh dari hasil interpretasi foto udara, pengecekan lapang, pengambilan dan analisis contoh tanah dan air serta informasi lainnya dari instansi terkait.

\section{Analisis Tingkat Bahaya Erosi dan Sedimentasi}

Untuk mempertahankan kelestarian produktivitas tanah maka perlu dicegah agar erosi yang terjadi tidak melebihi batas erosi yang dapat diabaikan. Besarnya erosi yang dapat diabaikan dihitung dengan rumus Achlil (1982):

$$
\mathrm{A}=4+1,266(10 \mathrm{D}-\mathrm{K}-2)
$$

dimana A: jumlah tanah hilang (ton/ha/th) yang dapat diabaikan, D: kedalaman solum tanah, dan K: indeks erodibilitas tanah. Dalam rekomendasi Rehabilitasi Lahan dan Konservasi Tanah diharapkan erosi dapat diturunkan sampai ke tingkat yang diabaikan.

Bahaya erosi atau jumlah tanah hilang maksimum (ton/ha/th) ditetapkan dengan menggunakan rumus USLE (Universal Soil Loss Equation) dari Smith dan Wischmeier (1978):

$$
\mathrm{A}=\mathrm{R} \times \mathrm{K} \times \mathrm{L} \times \mathrm{S} \times \mathrm{C} \times \mathrm{P}
$$

dimana A: jumlah tanah hilang maksimum (ton/ha/th), R: faktor erosivitas hujan, K: faktor erodibilitas tanah, LS: faktor panjang dan kemiringan lereng, C: faktor indeks pengelolaan tanaman, dan P: faktor indeks konservasi tanah. Nilai dari faktorfaktor $\mathrm{R}, \mathrm{K}, \mathrm{L}$, dan $\mathrm{S}$ ditetapkan dengan menggunakan rumusan tertentu dengan data dari hasil-hasil penelitian ini (data sekunder dan pengamatan lapangan), sedangkan nilai $\mathrm{C}$ dan $\mathrm{P}$ diduga dari data hasil-hasil penelitian terdahulu. Tingkat bahaya erosi ditetapkan berdasarkan kelas/besarnya bahaya erosi (ton/ha/th) dan kedalaman solum $(\mathrm{cm})$.

Analisis sedimentasi atau bahan terangkut akibat erosi diperlukan untuk mengetahui berapa jumlah bahan yang diendapkan di bagian hilir serta kerusakan yang dapat ditimbulkan bila bahan terangkut tersebut melewati pintu-pintu saluran irigasi. Beberapa contoh air dianalisis di Laboratorium untuk mengetahui sifat kimia atau kualitas air untuk irigasi dan air minum serta jumlah lumpur/bahan sedimen yang terangkut.

\section{Analisis Aliran Permukaan dan Peresapan Air Hujan}

Pendekatan atau asumsi yang digunakan adalah semakin besar tingkat resapan (infiltrasi) air hujan maka makin kecil aliran permukaan sehingga air hujan lebih banyak masuk ke dalam tanah, fluktuasi air tanah pada musim penghujan dan musim kemarau dapat diturunkan dan dapat meningkatkan cadangan air tanah.

Identifikasi daerah resapan dilakukan dengan cara overlay (tumpang tindih) Peta Potensi Infiltrasi dengan Peta Penggunaan Lahan. Peta potensi infiltrasi diperoleh dengan tumpang tindih peta-peta: penyebaran hujan, jenis tanah dan kelas lereng. Pengaruh kelas lereng terhadap tingkat resapan (infiltrasi), hubungan permeabilitas tanah dengan tingkat infiltrasi, potensi infiltrasi untuk setiap jenis tanah, klasifikasi nilai hujan infiltrasi, dan penilaian tingkat infiltrasi aktual mengacu kepada hasil-hasil penelitian Chow (1968), Hammer (1978), Suwardjo (1975), dan USDA (1951)

\section{HASIL DAN PEMBAHASAN}

\section{Bahaya Erosi dan Tingkat Bahaya Erosi}

Prediksi erosi dengan model USLE dikatakan oleh dapat mrnjelaskan kondisi erosi yang mempertimbangkan faktor tanah, tanaman dan aliran permukaan, meskipun beberapa faktor lain mungkin harus dipertimbangkan (Kinell \& Risse, 1998). Hasil perhitungan bahaya erosi dibedakan dalam 5 kelas bahaya erosi, yaitu kelas I $(<15$ ton/ha/tahun), kelas II (15-60 ton/ha/tahun), kelas III (60-180 ton/ha/tahun), kelas IV (180-480 ton/ha/tahun) dan kelas V ( $>480$ ton/ha/tahun) dengan luasan masing-masing tertera dalam Tabel 1.

Lahan dengan bahaya erosi kelas I tergolong rendah, menyebar cukup luas pada berbagai kondisi lereng, mulai dari $0 \%$ sampai lebih dari $40 \%$. Penggunaan lahan berupa sawah irigasi, sawah tadah hujan, semak belukar, kebun campuran dan hutan. Rendahnya bahaya erosi selain karena kemiringan lereng rendah, juga karena teknik konservasi berupa teras telah diterapkan petani di lahan berlereng, serta penggunaan lahan dengan komoditas dengan kontribusi erosi rendah. 
Tabel 1. Kelas bahaya erosi dan luasannya di daerah aliran sungai Cilengusi

\begin{tabular}{ccrr}
\hline \multirow{2}{*}{ Kelas Bahaya Erosi } & \multirow{2}{*}{ ton/ha/tahun } & Ha & \multicolumn{2}{c}{ Luas } \\
\cline { 3 - 4 } & & 17.820 & 33,00 \\
I & $<15$ & 7.892 & 14,78 \\
II & $15-60$ & 4.427 & 8,19 \\
III & $60-180$ & 2.898 & 5,37 \\
V & $180-480$ & 3.033 & 5,62 \\
Kawasan Pemukiman dan & $>480$ & & 3,04 \\
Industri*) & & 17.840 & 100,00 \\
Total & & 54.000 & \\
\hline
\end{tabular}

*): Kawasan Pemukiman dan Industri tidak ditetapkan tingkat bahaya erosinya.

Lahan dengan bahaya erosi agak berat sampai berat termasuk kelas IV dan kelas V mempunyai penyebaran sempit pada lahan berlereng $>8 \%$ dengan penggunaan lahan tegalan, kebun karet dan kebun campuran yang tidak terawat baik. Tingkat bahaya erosi ditentukan berdasarkan bahaya erosi dan kedalaman solum tanah. Solum tanah di daerah penelitian bervariasi dari dalam $(>90 \mathrm{~cm})$ sampai sangat dangkal $(<30 \mathrm{~cm})$. Sebagian besar solum tanah tergolong dalam sampai sedang dan hanya sebagian kecil saja yang bersolum dangkal dan sangat dangkal, yaitu sekitar 6.162 ha atau $11 \%$ dari yaitu kebun campuran, tegalan, sawah tadah hujan, belukar dan hutan.

Penyebaran lahan dengan tingkat bahaya erosi sedang (S) terdapat di lahan berlereng 0->40\% dengan penggunaan lahan pada umumnya adalah tegalan dan kebun campuran. Di beberapa tempat, lahan juga diusahakan untuk kebun kelapa dan rumput. Lahan dengan tingkat bahaya erosi berat (B) menyebar pada lahan berlereng lebih dari 3\% dengan penggunaan lahan berupa tegalan dan kebun campuran. Sedangkan lahan dengan tingkat bahaya

Tabel 2. Tingkat bahaya erosi dan luasannya di daerah aliran sungai Cilengusi

\begin{tabular}{lcc}
\hline \multicolumn{1}{c}{ Tingkat Bahaya Erosi } & \multicolumn{2}{c}{ Luas } \\
\cline { 2 - 3 } & Ha & $\%$ \\
\hline Sangat Ringan (SR) & 10.760 & 19,93 \\
Ringan (R) & 6.682 & 12,37 \\
Sedang (S) & 7.178 & 13,29 \\
Berat (B) & 6.598 & 12,22 \\
Sangat Berat (SB) & 4.942 & 9,15 \\
Kawasan Pemukiman dan Industri*) & 17.840 & 33,04 \\
\hline Total & 54.000 & 100,00 \\
\hline
\end{tabular}

*) Tingkat bahaya erosi tidak ditentukan.

luas daerah penelitian. Sub DAS Cileungsi terbagi dalam 5 tingkat bahaya erosi, yaitu sangat ringan, ringan, sedang, berat dan sangat berat dengan masing-masing luasan tertera pada Tabel 2.

Daerah/lahan dengan tingkat bahaya erosi sangat ringan (SR) menyebar pada berbagai kondisi lereng $(0->40 \%)$ dengan pengunaan lahan berupa sawah irigasi, sawah tadah hujan, hutan, belukar dan kebun campuran. Daerah dengan tingkat bahaya erosi ringan $(\mathrm{R})$ menyebar pada berbagai kondisi lereng $(0->40 \%)$ dan berbagai penggunaan lahan, erosi sangat berat (SB) dijumpai pada lereng lebih dari $8 \%$ dengan penggunaan lahan berupa tegalan, kebun campuran dan perkebunan karet.

Intensifikasi sistem pertanian dengan manajemen intensif pada jangka panjang dapat menyebabkan erosi, dengan kecepatan erosi di sistem pertanian tropis lebih cepat daripada kecepatan pembentukan tanah (Sparovek \& Schnug, 2001). Di daerah studi, tingkat bahaya erosi yang agak berat dan berat ternyata terdapat di lahan perkebbunan dengan kemiringan tinggi. Dengan 
demikian untuk melestarikan tanah seharusnya daerah ini direhabilitasi dengan tanaman kehutanan.

\section{Kondisi Daerah Resapan}

Kondisi daerah resapan dapat diklasifikasikan dengan cara membandingkan infiltrasi potensial dan infiltrasi aktual serta nilai erosi aktualnya. Kondisi resapan daerah kajian dapat diklasifikasikan atas 4 kriteria, yaitu baik, normal alami, mulai kritis dan agak kritis. Sedangkan kondisi resapan kawasan pemukiman dan industri tidak ditetapkan. Adapun luasan masing-masing kondisi daerah penelitian tertera pada Tabel 3 .
Cerdà, (1999), keberadaan vegetasi meningkatkan resapan dan mengurangi aliran permukaan dan erosi.

Tingginya fluktuasi debit air sungai antara musim hujan dan musim kemarau merupakan permasalahan yang sering terjadi di Sub DAS Cileungsi. Pada musim hujan air sungai sering meluap dan keruh berwarna coklat yang merupakan tanda tingginya laju aliran air permukaan dan besarnya erosi yang terjadi di hulu. Penyebab utama terjadinya degradasi lahan akibat erosi adalah tanah tanpa vegetasi dan teknik konservasi tanah dan air kurang diterapkan.

Tabel 3. Kondisi resapan dan luasannya di sub daerah aliran sungai Cileungi

\begin{tabular}{|c|c|c|c|}
\hline \multirow{2}{*}{ Kelas } & \multirow{2}{*}{ Kriteria/kondisi } & \multicolumn{2}{|c|}{ Luas } \\
\hline & & $\mathrm{Ha}$ & $\%$ \\
\hline I. & Kondisi Baik & 10.076 & 18,66 \\
\hline II. & Normal Alami & 6.158 & 11,40 \\
\hline III. & Mulai Kritis & 12.398 & 22,96 \\
\hline IV. & Agak Kritis & 7.528 & 13,92 \\
\hline \multicolumn{2}{|c|}{ Kawasan Pemukiman dan Industri } & 17.840 & 33,04 \\
\hline \multicolumn{2}{|l|}{ Total } & 54.000 & 100,00 \\
\hline
\end{tabular}

Kondisi daerah resapan baik (Kelas I) menunjukkan bahwa infiltrasi potensial yang dipengaruhi oleh faktor lereng, tanah dan curah hujan lebih besar dibandingkan dengan infiltrasi aktualnya yaitu penggunaan lahannya. Artinya bahwa faktor lereng, tanah dan curah hujan lebih berpengaruh dalam meresapkan air ke dalam tanah dibandingkan dengan penutup tanahnya. Kondisi normal alami (Kelas II) menunjukkan infiltrasi aktual dan potensial sama. Artinya walaupun sifatsifat tanah (terutama tekstur), lereng dan curah hujan kurang mendukung peresapan air ke dalam tanah, namun dengan penutupan lahan yang cukup baik maka kondisi resapan air tanah tetap terjaga. Kondisi mulai kritis (Kelas III) menunjukkan nilai infiltrasi aktual sudah turun satu tingkat dari infiltrasi potensialnya, artinya vegetasi penutup lahannya sudah tidak mendukung resapan air ke dalam tanah. Sedangkan kondisi agak kritis (Kelas IV) menunjukkan infiltrasi aktual sudah turun dua tingkat dari infiltrasi potensialnya, artinya vegetasi penutup lahannya sudah semakin tidak mendukung resapan air ke dalam tanah. Hal ini menunjukkan bahwa lahan sudah terdegradasi karena menurut
Penyebab utama kerusakan lahan di daerah kajian adalah sistem pertanian lahan kering tanpa penerapan teknik konservasi tanah dan air yang memadai. Akibatnya degradasi lahan dan penurunan produktivitas lahan terus berlanjut. Proses alih fungsi lahan pertanian menjadi non-pertanian seperti kawasan industri dan pemukiman juga menurunkan daya sangga air sehingga air hujan tidak tertahan lama di lahan pertanian. Hal ini terlihat dari seringnya air sungai meluap pada saat hujan dan segera surut setelah hujan berhenti. Kondisi ini mempengaruhi tingginya fluktuasi air sungai antara musim hujan dan musim kemarau yang turut mempengaruhi ketersediaan air bagi penduduk di dalam dan di luar kawasan Sub DAS Cileungsi.

\section{SIMPULAN}

1. Berdasarkan perhitungan bahaya erosi, daerah kajian terbagi atas 5 kelas bahaya erosi, yaitu kelas I (<15 ton/ha/th) seluas 17.820 ha (33\%), kelas II (15-60 ton/ha/th) seluas 7.892 ha (14,78\%), kelas III (60-180 ton/ha/th) seluas 
4.427 ha $(8,19 \%)$, kelas IV (180-480 ton/ha/th) seluas 2.898 ha $(5,37 \%)$, dan kelas V (>480 ton/ha/th) seluas 3.033 ha $(5,37 \%)$. Perhitungan bahaya erosi pada kawasan industri dan pemukiman tidak dilakukan.

2. Tingkat bahaya erosi dibedakan dalam 5 tingkat, yaitu: sangat ringan (SR) seluas 10.760 ha $(19,93 \%)$, ringan $(\mathrm{R})$ seluas 6.682 ha $(12,37 \%)$, sedang (S) seluas 7.178 ha $(13,29 \%)$, berat (B) seluas 6.598 ha $(12,22 \%)$, dan sangat berat (SB) seluas 4.942 ha $(9,15 \%)$. Pada lahan dengan tingkat bahaya erosi berat sampai sangat berat umumnya terdapat di bagian hulu Sub DAS perlu ditangani serius.

3. Kondisi resapan daerah kajian dikelompokkan kedalam 4 kondisi, yaitu: kondisi baik seluas 10.076 ha $(18,66 \%)$, kondisi normal alami seluas 6.158 ha $(11,40 \%)$, kondisi mulai kritis seluas 12.398 ha $(22,96 \%)$ dan kondisi agak kritis seluas 7.528 ha $(13,94 \%)$. Kurangnya penutup lahan pada bagian hulu Sub DAS merupakan salah satu faktor penyebab rendahnya kemampuan tanah meresap air, menahan air hujan dan aliran permukaan.

\section{UCAPAN TERIMAKASIH}

Kajian ini dilakukan atas kerjasama dengan Pemerintah Kabupaten Bogor cq. Dinas Kehutanan dan Perkebunan dan Fakultas Pertanian Universitas Padjadjaran Bandung

\section{DAFTAR PUSTAKA}

Achlil, K., 1982. Kriteria lahan kritis dalam rangka Program Penyelamatan Hutan, Tanah dan Air. Proyek Pusat Pengembangan Pengelolaan DAS di Solo.

Cerdà, A. 1999. 1999. Parent material and vegetation affect soil erosion in eastern spain. Soil. Sci. Soc. Am. J. 63:362-368
Chow, V. T., 1968. Handbook of Applied Hydrology, McGraw-Hill Book Co. New York.

Dinas Kehutanan dan Perkebunan Kabupaten Bogor. 2002. Penyusunan RTL-RLKT sub DAS Cileungsi. Dinas Kehutanan dan Perkebunan Kabupaten Bogor. Bogor

FAO, 1989. Water Quality for Agriculture, Ayer and D. W. Westcot. Irrigation and Drainage. Paper No. 29 Rev. 1 Rome 10 p

Hammer, W. I., 1978. Soil Conservation Consultant Report; INS/78/006. Technical Note No. 7. Soil Research Institute Bogor. $72 \mathrm{p}$.

Kinnell, PIA and L.M. Risse. 1998. USLE-M: Empirical modeling rainfall erosion through runoff and sediment concentration. Soil Sci. Soc. Am. J. 62:1667-1672

Smith, D. D. And Wischmeier, W. H., 1978. Predicting Rainfall Erosion Losses - A Guide to Conservation Planning. Agriculture Handbook 537. US Department of Agriculture.

Sparovek, G. and E. Schnug. 2001. Temporal erosion-induced soil degradation and yield loss. Soil Sci. Soc. Am. J. 65:1479-1486

Suwardjo, 1975. Beberapa Data dan Masalah Konservasi Tanah untuk Pencegah Erosi. Seksi Konservasi Tanah dan Air. Lembaga Penelitian Tanah Bogor, Report No. 11.

Tan, K. H. 1991. Dasar-Dasar Kimia Tanah. Terjemahan Goenadi, D.H. Gajah Mada University Press. Yogyakarta.

USDA, 1951. Soil Survey Staff. Soil Survey Manual, Agriculture Handbook No. 18. US Department of Agriculture.

Yusmandhany, E.S. 2004. Kemampuan potensial lahan menahan air hujan dan aliran permukaan berdasarkan tipe penggunaan lahan di daerah Bogor bagian tengah. Bul. Tek. Pertanian 9:26-29 